\title{
The Money Factor from the Perspective of the Adherents of a Subsistence Economy and Mercantilism
}

\author{
Yakov Yadgarov \\ Department of Economic Theory \\ Financial University under the Government of the Russian Federation \\ Moscow, Russia \\ E-mail: Yakovyadgarov@mail.ru
}

\author{
Sergei Tolkachev \\ Department of Economic Theory \\ Financial University under the Government of the Russian \\ Federation \\ Moscow, Russia \\ E-mail: satolkachev@fa.ru
}

\author{
Vladimir Ostroumov \\ Department of Economic Theory \\ Financial University under the Government of the Russian \\ Federation \\ Moscow, Russia \\ E-mail: Ostroumov.v@mail.ru
}

\begin{abstract}
The purpose of this work is to outline general and special aspects in different perceptions of the place and role of money and money circulation in economic life. This is done by means of historical and economic analysis of the views of the adherents of subsistence economic ideology in the Ancient world and the Middle Ages, as well as of the views of mercantilists, who were the pioneers of market economic ideology. The objective was to show substantial aspects of conventional money theory existed in these time periods and include alternative versions, such as nominalist, metallist, and quantity theories. Within the study, the authors analyse not only moral and ethical aspects of the natural economic "money ideology" but also the views of rulers, scholars, and philosophers of ancient Oriental and Antique states. The theoretical and methodological principles of so-called early and late mercantilists led to the transition from the "metallist" to the "quantity" theory, and from the system of bimetallism to the system of monometallism are shown. One of the results of the analysis is a comparative description of the understanding of the monetary factor in the early and late mercantilism era. Among the conclusions is the provision that the results of the research presented herein will contribute to subsequent scientific research in the field of money theory and measures to improve the sphere of money circulation at the present time.
\end{abstract}

Keywords-money factor; nominalist theory of money; metallist theory of money; quantity theory of money; functions of money; subsistence economy; market economy

\section{INTRODUCTION}

From a historical prospective, the money factor has been the focus of many researchers of money problems over the years, from the evolution of economic attitudes and ideas to the modern stage of economic evolution. Adherents of reform concepts aimed at transforming the monetary sphere, considering the special role of this factor in all aspects of public life, have also considered the money factor.

This is clearly reflected, first, in natural economy "money ideology". Towering achievements are considered, from interpretations of the essence and purpose of money by rulers, scholars, and philosophers of ancient Oriental and Antique public entities until medieval times in those countries in which interpretation of the purpose of the money was seen through the prism of religious, philosophical, and moralethical maxims by leaders of Christianity and Islam. Second, the creative legacy in the field of the theory of money and money circulation is reviewed, beginning with the first adherents of market economic ideology, i.e. political economy research of early and late mercantilists with their commitment to the policy of economic protectionism.

All possible research versions of theoretical comprehension of money and the money factor are considered. The evolution of economic life and theoretical knowledge about money, including such well-known interpretations of this theory as metallist, nominalist, and quantity, seem to have been presented over the indicated period of time. However, in academic circles, there has never been a shared opinion on either what constituents in alternative theories of money should be considered as orthodox and why or what scientific schools or directions of economic thought have failed to give a "true scientific" interpretation of this theory and when. Taking these circumstances into consideration, one can see below the results of an analytical review of the features of the evolution of economic perceptions of the currency factor, starting with research materials of relevant periods of subsistence agriculture to contemporary adherents of nominalist and metallist versions of money theory, and finishing with early 
and late periods of mercantilism, which subsequently contributed to the development of new research preferences a quantity version of money theory.

\section{METHODS}

Historical and economic focus of the research determined the implementation of the following methods and analytical approaches:

- Empirical method, using moral-ethical and moral analytical approaches (in the perceptions of the adherents of natural economy ideology, as well as of the adherents of mercantilism);

- Causal method in the works of the late representatives of mercantilism in justifying the roots of the growth of monetary wealth in the sphere of money circulation and of a leading role of monetary factors and external trade in economy.

\section{RESULTS}

\section{A. Natural Economy Monetary Ideology: Essence and Features}

Nowadays, it is common knowledge that the first evidence of what is money and what functions it "should have" in public use, emerged in the era of the domination of the natural-economic relations with the simultaneous creation of the first public entities. In particular, according to the ancient Chinese treatise "Guanzi" and ancient Indian treatise "Arthashastra" which gained popularity in 4th-3rd centuries BC, such items as gold and measures of calculation of State resources was explained by its natural destiny to act as money. In addition, it was to facilitate exchange, contributing to the situation where the "benefits of some" are "bigger than the benefits of the others".

It is necessary to add that this kind of moral-ethical and moral perception of the money factor was held by not only rulers and thinkers of ancient Eastern countries of that time, but also the very famous ancient Greek philosophers of the 4th century BC: Xenophon, Plato, and Aristotle [1] [2] [3]. They also believed that money did not have a natural origin but that it stemmed from the law and it was a socially accepted means for measuring the cost of goods. From their perspective, exclusively with ethical positions, one can give true characteristics both to money and to various economic phenomena and most common related concepts (categories), including (along with money) the production, exchange, distribution, need, etc.

For example, Xenophon's treatise "Oeconomicus" and Aristotle's works "Nicomachean Ethics» and "Politics" are focused on the provision that money was invented by people in order to implement the circulation of goods and accumulation of wealth. They rejected the phenomenon of "unnatural" to the usurious nature of enrichment, without hiding their supportive attitude to natural economic principles in the economic life of society. Aristotle, putting forward the concept of economy and chrematistics, claimed that the latter (chrematistics) is absolutely immoral and unethical, because it is based on the unscrupulous major trade-brokering operations for profit, i.e. increasing possession of money.

It is necessary to specify an Aristotelian passage, quite often referred to in the economic literature, according to which the total cost of the five lodges can be equal to the value of one house, as their commensurability is achieved only because of money. Here, as in other parts of the money factor understanding, once again it is obvious that Aristotle, talking about commodity exchange through money, puts moral and ethical values in the foreground. The philosopher meets usury with a "justified hatred" as "pre-eminently ugly to nature" because "it makes banknotes themselves the subject of ownership, thus making them lose their purpose, for they were created for the sake of barter, changing the focus to the growth of money [3].

In the middle ages, the moral grounds for understanding of a monetary factor were, with some assumptions, backed up by a theological component of Islam and Christianity, the ideological voice of which was expressed by the leaders of religious instructions of the time. According to the Koran preacher and the teacher of the "Social Physics" Ibn-Haldun (14th century), famous in Arab countries and in North Africa as a philosopher, money is the most important element of economic life. However, in his eyes, it is necessary to fulfil the purpose of high-grade coins (for counting) made of gold and silver, metals "created by the God". At the same time, Ibn Haldun did not deny that money item displays the quantitative content of human labour "in everything bought", the cost of "any movable property" and a nominal "basis of acquisition, stockpiling and treasures" [4].

Thomas Aquinas, the bright adept of medieval Catholicism of the school of later canonists (13th century), in his book "Summa Theologiae", has a dual and compromise position with Ibn Khaldun on the nominalist interpretation of the concepts of money and money exchange. Aquinas shared the perception of money of the ideologues of the ancient world with the recognition that the reason for their emergence is the expression of the will of the people for possession of "right measure" in "trade and trafficking". At the same time, the philosopher admits that, although money has "intrinsic value ", the State can allow some deviation of value of coins from its "intrinsic value". Moreover, according to Aquinas, the seller can rightfully sell "a thing for a higher price than it worth", and it "will not be sold for a higher price than it costed to the owner", because there will be damage for a seller whose revenues will not correspond to his social status, as well as the entire "public life". However, one cannot but agree with Aquinas that "people are divided into various groups according to their occupation, for it is nature that determines the inclination of different people to different professions." [5].

These are the origins of the first nominalist monetary theories, based on the characteristics of metal coins as nothing more than symbols of their cost. And this is the background for the emergence of the classical nominalism in the theory of money, often mentioned in political literature in the context of the beliefs of Roman and medieval jurists. 
Indeed, the latter insisted that money, as a product of a State authority, represent some ideal counting units designed to serve the exchange of goods, and that the practice of "deliberate damage of coins" by the governments (on behalf of the higher power - the state, which by its mark gives value to money) is inherently justified.

\section{B. The Money Factor from the Perspective of the Adherents of Mercantilism}

In the era of mainstream transition to market economic relations and the origin of economic science, theoretical and methodological settings of mercantilism were dominated by such so-called mercantilist guidelines as protectionist sentiments in State regulation of foreign trade, and the equation of money and monetary wealth, for full multiplication of which public works and the other postulates were endorsed. These settings entail conclusions about "the duty" of the State to provide the population with jobs, and to practice "beggar-thy-neighbour" policies in order to enrich its own people.

However, understanding the money factor began to experience significant transformations as the mercantilist theoretical-methodological paradigm came forward in ideological struggle with natural economy ideology. It was the adherents of mercantilism during the early (16th - early 17 th centuries) and late (17th -18 th century) periods who concentrated at first on the metal, and then on quantity interpretations of monetary theory and related mechanisms of monetary circulation [6].
Early mercantilists believed that the appearance of money resulted from an artificial invention of people and that money is to be equated with wealth. The origin of the time value of money is linked to the "nature" of gold and silver money, as well as its amount in the country. In addition, during the period of early mercantilism, an understanding of the illegality of the nominalist version of the theory of money dating back to ancient times appeared. Reflections of the early mercantilists testified that nominalists fundamentally deny the commodity nature of money as well as its connection with precious metals.

Early mercantilists, as it happened in the medieval period, called for the governmental "damage" of the national currency to reduce its cost (value) and weight. The transformation of gold and silver money into a symbol and its fixed ratio was explained by the fact that circulation of substandard coins and erroneous recognition of the statement that gold and silver are money thanks to their natural features.

Representatives of the late mercantilism, recognizing the commodity essence of money, still linked the value of the coins with the natural features of gold and silver.

The emergence of a quantity theory of money was actually a natural reaction to the so-called "price revolution" of the 16th century, which occurred due to a huge influx of gold and silver into European countries from the New World. This influx, in fact, showed the interconnectivity of the quantity of money and commodity prices.

Specifics of understanding of the money factor by early and late mercantilists can be briefly described as follows:

TABLE I. UNDERSTANDING OF A MONEY FACTOR BY EARLY AND LATE MERCANTILISTS

\begin{tabular}{l} 
Early mercantilism \\
\hline Positions concerning monetary theory \\
The nominalist perception of money prevails; the Government \\
usually corrupts national currency, reducing its value and weight;
\end{tabular}

A fixed ratio of gold and silver in circulation of money (bimetallism) is set;

Acknowledgement of the monetary essence of gold and silver due to their natural properties;

The following functions of money are recognized: unit of accounting, formation of world treasures, and global money.

Monetarists position

The idea of "cash balance" dominates.

Considering the principles of early and late mercantilists, it is not difficult to notice that they are ill-considered and groundless. So, such well-known (as widely recognized as Thomas Mun and Jean-Baptiste Colbert, often referred to in the economic literature) mercantilists as John Locke and Richard Cantillon insisted that the greater amount of gold and silver in a particular country compared with other countries determines a higher level of wealth in that country.

However, in the works of the latter author, this conclusion does not seem so unambiguous. R. Cantillon was one of the founders (if not a pioneer) of the method of abstract theorizing, and a forerunner of classical political
Late mercantilism

The "price revolution" of the 16th century led to the transition to a quantitative theory of money (value for money is in inverse proportion to its amount; the price level is in direct proportion to the amount of money; the growth of the money supply, increasing demand for them, stimulates trade); Monometallism is implemented;

Acknowledgement of the mercantile essence of money, but still due to supposedly natural properties of gold and silver;

Among the many functions of money, the function as a store of value is no longer recognized as a defining one, but the function as a medium of exchange is.

The idea of "trade balance" is widespread.

economics. He did not consistently share mercantilist views on the essence of wealth. In one of the contemporary research papers, it is proven that, in his work, Cantillon denied a monetarist quantity theory of money [8]. Mark Thornton believes that "Cantillon divorced mercantilism on the issue of equating of wealth with money, when he wrote that "wealth is essentially nothing more than support, facilities and luxuries of life" [9]. As Cantillon discovered the foreign balance law based on the flow of gold and offsetting changes in the exchange rate, he could not but see a supportive role of money in the national economy. 
However, Cantillon, a supporter of a positive trade balance, still recommended to accumulate gold reserves, though he acknowledged the impossibility of this policy in the long term. These are his reasons to accumulate gold for the growth of national wealth in the country:

First, Cantillon was one of the first who noticed the effect of favourable (positive) conditions of trade. If gold flows into a country, the prices for all goods, and each unit of exports will be exchanged for a larger amount of imports. Just as in Russia, a German car which has a high price, including high wages of German workers, will be equivalent to a greater amount of Russian oil, than, for example, a Chinese car.

Second, unlike other mercantilists, Cantillon divided cash flow into two categories: as a means of circulation and as capital funds (long-term loans and direct investment). He unequivocally welcomed the inflow of gold in the form of foreign investments, for they raise national production and increase productivity.

And third, he saw accumulation of a gold fund as an antiwar instrument, believing that a large gold stock tempered the fervour of those about to attack the country. This is the philosophy he brought to the "reverse" principle, since he personally experienced the endless wars led by French kings which devastated his country's coffers.

\section{DISCUSSION}

The results of the research show that, from the natural economy models of public and economic life to the birth of the first mercantilist models of the market economy system, there existed various general and particular aspects of "monetary ideology". The general aspects: natural economy adepts (ideologists of the ancient world and middle ages) and then early and late mercantilists, pioneers of market economic ideology, attached great importance to the role of money in human life, unanimously agreeing that the monetary factor should be recognized as an artificial human invention. Believing thus, they even considered that the use of money was not predetermined either in the past or in the present.

A mistake in their judgments is obvious. First, due to the fact that in the period of mercantilism domination and related full expansion of commodity and money relations, nominalist and metallist versions of money theory of the followers of natural economy were finally driven out by socalled quantity interpretation of this theory. And, second, thanks to the mercantilists, the statement that "money is created by money" is not considered as immoral or sinful. This is an inherent feature of a market economy system.

Meanwhile, it should be noted that, in subsequent periods of economic life and economic science evolution, the postulates of ideologues of both natural economy and mercantilism would manifest in the concept that the value of the monetary factor should not be exaggerated, and that money could finally be "abolished". It is known, for example, that Pierre Le Pesant de Boisguilbert was one of the first "classics" of political economy who argued against an unnatural turning of money into "idols". Economist romantic Pierre-Joseph Proudhon and Karl Marx, one of the pioneers of values of classical political economy, were certain about the "abolition" of money in the ideal future society.

\section{CONCLUSION}

Using historical and economic analysis, this paper presented a comparative overview of the evolution of the views of the adherents of natural economy and mercantilism on the place and role of the monetary factor in public life. From this, it is possible to formulate the following conclusions. First, the analytical and comparative results of this research will help to streamline and systematize knowledge about the nature, place and role of monetary factors in the context of the evolution of economic life. And, second, these results will provide a base for further research on the theory of money and reformatory concepts aimed at development and implementation of alternative measures to improve and enhance the scope of money circulation.

\section{REFERENCES}

[1] Xenophon of Athens, Socratic writings, M. - L.: Academy XXIV, 1935.

[2] Plato, Writings in 3 volumes, M., 1968-1972.

[3] Aristotle, Writings in 4 volumes, M.: Thought, 1975-1983, vol. 4, p. 395.

[4] Ya.S. Yadgarov, History of economic teaching: Textbook, 4th ed., revised, M .: INFRA-M, 2003, p. 56.

[5] M. Veber, Selected works, M.: Progress, 1990, p. 129.

[6] Mercantilism / I.S. Plotnikova (ed.), M.: Sotsekgiz, 1938.

[7] Ya.S. Yadgarov, History of economic teaching, pp. 67-68.

[8] Richard van den Berg, Richard Cantillon's Early Monetary Views? Economic Thought, Vol. 1, No. 1, 2012, pp. 49-72.

[9] Mark Thornton, Was Richard Cantillon a Mercantilist? Journal of the History of Economic Thought, Vol. 29, No. 4, Dec. 2007, pp.417-435. 